\title{
Effect of phosphate buffer on aggregation kinetics of citrate-coated silver nanoparticles induced by monovalent and divalent electrolytes
}

\author{
Afshinnia $\mathrm{K}$ and Baalousha $\mathrm{M}^{*}$ \\ Center for Environmental Nanoscience and Risk, Department of Environmental Health Sciences, Arnold School of \\ Public Health, University South Carolina, Columbia, SC 29208, USA \\ * Corresponding Author: mbaalous@mailbox.sc.edu
}

\begin{abstract}
The attachment efficiency $(\alpha)$ is an important parameter that can be used to characterize nanoparticle (NPs) aggregation behavior and has been a topic of discussion of several papers in the past few years. The importance of $\alpha$ is because it is one of the key parameters that can be used to model NP environmental fate and behavior. This study uses UV-vis and laser Doppler electrophoresis to monitor the aggregation behavior of citrate-coated silver nanoparticles (citAgNPs) induced by $\mathrm{Na}^{+}$and $\mathrm{Ca}^{2+}$ as counter ions in the presence and absence of Suwannee River fulvic acid (SRFA) as a surrogate of natural organic matter and different concentrations of phosphate buffer (0-1 mM). Results demonstrate that phosphate buffer, which serves to maintain $\mathrm{pH}$ nearly constant over the course of a reaction, is an important determinant of NP aggregation behavior. Increasing phosphate buffer concentration results in a decrease in the critical coagulation concentrations (CCC) of cit-AgNPs to lower counter ion concentration and an increase of $\alpha$ at the same counter ion concentration, both in the absence and presence of SRFA. SRFA stabilizes AgNPs and increases the CCC to higher counter ion concentrations.

The outcome of this study can be used to rationalize the variation in $\alpha$ and CCC values reported in the literature for NPs with similar physicochemical properties, where different $\alpha$ and $\mathrm{CCC}$ values are reported when different types of buffers and buffer concentrations are used in different studies.
\end{abstract}




\section{Introduction}

Silver nanoparticles (AgNPs) are nowadays used in a large number of commercial products due to their antimicrobial properties ${ }^{1}$, resulting in release of AgNPs to the environment $^{2,3}$, with estimated surface water concentrations in the ng to $\mu \mathrm{g} \mathrm{L}^{-1}$ range. ${ }^{4,5}$ Once in the environment, AgNPs undergo several transformations such as dissolution ${ }^{6}$, aggregation $^{7}$, sulfidation ${ }^{8}$, photochemical, and biological transformations. $^{9-11}$ These transformations of AgNPs can impact their fate and effects in the environment. ${ }^{9-11}$ Nanoparticle (NP) aggregation is one of the key processes determining their reactivity ${ }^{12-14}$, bioavailability $^{15,16}$, toxicity $^{17-20}$ and environmental fate and effects. ${ }^{16}$

Silver nanoparticle aggregation is governed by the physicochemical properties of the NPs (e.g. size, shape, surface charge, and concentration) and the media (e.g. $\mathrm{pH}$, ionic strength, counter ion valency, and presence of natural organic macromolecules). ${ }^{7,21,22} \mathrm{NP}$ suspension stability is typically characterized by two fundamental parameters (attachment efficiency, $\alpha$; and critical coagulation concentration, CCC). The attachment efficiency reflects the fraction of NP collisions leading to attachment of two NPs and is $<1.0$ under reaction limited aggregation regime (RLA) and equals 1 under diffusion limited aggregation regime (DLA). ${ }^{23}$, ${ }^{24}$ The Critical coagulation concentration (CCC) is the minimum concentration of counter ions required to completely destabilize the NP suspension. The attachment efficiency $(\alpha)$ has been recently a focus of discussion due to its importance to construct NP fate models. ${ }^{16,25}$ Thus, the recent spike in publications of empirically determined $\alpha$ 's or related parameters (e.g. Debye length) for use in such models. ${ }^{7,23,26-30}$ Nonetheless, there is still a need to better understand the factors determining $\alpha$, among which NP and medium physicochemical properties $^{29,30}$.

Buffering NP suspensions to maintain a constant $\mathrm{pH}$, when investigating environmental fate, behavior and effects of NPs is of utmost important to minimize confounding results due to changes in $\mathrm{pH}$ in case of the absence of buffer. Several studies have demonstrated that suspension $\mathrm{pH}$ affect NP surface charge and aggregation behavior. ${ }^{12,28,31-36}$

For instance, Stemig et al. (2014) reported an increase in goethite NP aggregate size and a decrease in their zeta potential with the increased concentration of MOPS (3Morpholinopropane-1-sulfonic acid) buffer. $^{12}$ Several studies have investigated the aggregation kinetics of AgNPs; some studies used buffer such as carbonate buffers to 
maintain a stable $\mathrm{pH}^{26,27,37}$, while others did not use any buffer to prevent interferences due to the presence of the buffer. ${ }^{7}, 38$ These studies have reported significant variability in the measured $\alpha$ and CCC values for citrate-AgNPs, which were attributed to differences in experimental conditions such as media composition (e.g. buffer type and concentration) and physicochemical properties of the particles such as particle size and surface coverage of the citrate molecules on the NPs. ${ }^{38,} 39$ However, none of these studies have systematically investigated the effect of buffer type and concentration on the aggregation behavior of AgNPs.

Therefore, the aim of this study is to assess the effect of phosphate buffer on the stability of citrate-AgNPs. The stability of AgNPs was quantified by measuring AgNP aggregation kinetics using UV-vis and determining the $\alpha$ and $\mathrm{CCC}$ in the presence of different concentrations of potassium phosphate monobasic (0 to $1 \mathrm{mM}$ ) as a representative buffer, sodium nitrate and calcium nitrate as monovalent and divalent electrolytes, and Suwannee River fulvic acid (SRFA) as a surrogate of natural organic matter (NOM). Here we use near environmentally-relevant AgNPs concentration (e.g. $270.25 \mu \mathrm{g} \mathrm{L}^{-1}$ ).. The concentration of AgNPs used in this study is less than those typically used in aggregation kinetic studies in the literature. ${ }^{38}$ However, it is still higher than those estimated to occur in environmental systems based on exposure modeling approaches. ${ }^{4}$, 40 Phosphate buffer was used as an environmentally and biologically relevant buffer in this study. ${ }^{41}$ Phosphate is commonly found in environmental ${ }^{42}$ and biological and toxicological media. ${ }^{43-45}$ In the human body, inorganic phosphate concentration ranges from 0.2 to $0.4 \mathrm{mM}$ and from $23 \mu \mathrm{M}$ to $1 \mathrm{mM}$ in human blood and sweat, respectively. Water bodies, such as rivers and lakes, may contain phosphate ion concentrations of 0.01 to $1 \mathrm{mM}$, although occasionally at higher concentrations following phosphorous pollution events and in wastewater effluent. ${ }^{46,47}$ With phosphate's significant presence in biological systems and in the environment, we pose the question as to whether the phosphate anions can have any influence on AgNP aggregation kinetics, and hence, the environmental fate, behavior and impact of AgNPs.

\section{Methodology}

\section{Synthesis and characterization of silver nanoparticles}


Citrate-coated silver nanoparticles (cit-AgNPs) were synthesized and characterized using a previously reported method. ${ }^{48}$ Briefly, solutions of $100 \mathrm{ml}$ silver nitrate $(0.25 \mathrm{mM}$, 99.9+\%, Alfa Aesar ), $100 \mathrm{ml}$ trisodium citrate (0.31 mM, 99.9+\%, British Drug Houses, $\mathrm{BDH})$ and sodium borohydride (10 mM, 98\%-Alfa Aesar) were prepared in ultrahigh purity water (resistivity $=18.2 \mathrm{M} \Omega . \mathrm{cm}$ ) and were then kept at $4 \circ \mathrm{C}$ in the dark for $30 \mathrm{~min}$. Silver nitrate and sodium citrate solutions were mixed together in a conical flask under continuous stirring condition. Afterward, $6 \mathrm{ml}$ of the solution of the reducing agent, sodium borohydride $\left(\mathrm{NaBH}_{4}\right)$, was added in one batch. After 10 min of stirring, the solution was heated slowly to boiling and then heated for a further $90 \mathrm{~min}$. The synthesized AgNP suspension was then stored in dark overnight and cooled to $4 \circ \mathrm{C}$. $200 \mathrm{ml}$ of AgNP suspension was cleaned by pressurized stirred ultrafiltration cell (Amicon, $1 \mathrm{kDa}$ regenerated cellulose membrane, Millipore) to remove the excess reagents before use. AgNP suspension volume was reduced to $100 \mathrm{ml}$ and then replenished by $100 \mathrm{ml}$ of $0.31 \mathrm{mM}$ trisodium citrate solution. This process was repeated at least three times to avoid further NP growth.

The concentration of the synthesized AgNPs was measured by inductively coupled plasma-atomic emission spectroscopy (ICP-OES). The total Ag Concentration in the stock suspension was $10.81 \mathrm{mgL}^{-1}$. The size and electrophoretic mobility (EPM) of AgNPs were measured by dynamic light scattering (DLS) and laser Doppler electrophoresis, respectively using a Malvern Zetasizer NanoZS Instrument (Malvern, USA). The Malvern Zeta potential transfer standard (DTS 1235) consisting of a polystyrene latex in aqueous buffer at pH 9 with a zeta potential value of $-42 \pm 4.2 \mathrm{mv}$ was used to verify the performance of the instrument and zeta potential cell throughout the experiments. According to DLS, the z-average hydrodynamic diameter and size polydispersity index of synthesized citrate-AgNPs in stock suspension were $24.5 \pm 0.1 \mathrm{~nm}$ and $0.21 \pm 0.05$, respectively, indicating a narrow size distribution. The zeta potential of the synthesized cit-AgNPs $(\mathrm{pH} 7.0)$ was $-41.7 \pm 2.0$ using Smoluchowski approximation. The standard deviation reported here shows the stability of the replicate measurements and was determined from 5 replicates of size and 10 replicates of zeta potential.

The optical absorbance spectrum of cit-AgNPs was collected by a UV-vis spectrophotometer. All spectra were collected using a $100 \mathrm{~mm}$ path length cuvette, which allows analysis of AgNPs at relatively low concentration $\left(270.25 \mu \mathrm{g} \mathrm{L}^{-1}\right){ }^{7}$ The UV-vis spectrum of 
AgNP stock suspension (10.81 $\mathrm{mg} \mathrm{L}^{-1}$ ) over wavelength 200-900 nm measured using a $10 \mathrm{~mm}$ path length cuvette shows a single peak centered at $396 \mathrm{~nm}$ (Fig. S1).

\section{Solution Chemistry}

The effect of phosphate buffer on the aggregation kinetics of cit-AgNPs at $\mathrm{pH} 7$ was investigated using UV-vis spectroscopy by varying the buffer concentration $(0-1 \mathrm{mM})$ in suspensions with different concentration of $\mathrm{NaNO}_{3}\left(99+\%\right.$, Sigma Aldrich) and $\mathrm{Ca}\left(\mathrm{NO}_{3}\right)_{2}(99+\%$ Alfa Aesar). First, a stock solution of $5 \mathrm{mM}$ potassium phosphate monobasic $(99.9+\%, \mathrm{BDH})$ was prepared and the $\mathrm{pH}$ was adjusted to 7.0 by adding $2 \mathrm{ml}$ of $1 \mathrm{M} \mathrm{NaOH}$ in 1 Liter of $5 \mathrm{mM}$ buffer. Then, the buffer stock solution was diluted to achieve different concentration of buffers (0-1 mM). The final concentration of $\mathrm{K}^{+}$and $\mathrm{Na}^{+}$added due to buffer solution and $\mathrm{pH}$ adjustment by $\mathrm{NaOH}$ are very small $c a$. $<0.4$ and $1 \mathrm{mM}$, respectively. Therefore, any differences in AgNPs aggregation kinetics, is due to the variation in phosphate buffer concentration (see detailed discussion below). $1 \mathrm{M} \mathrm{NaNO}_{3}$ and $3 \mathrm{mM} \mathrm{Ca}\left(\mathrm{NO}_{3}\right)_{2}$ electrolyte solutions were prepared in ultrahigh purity water or diluted buffer. Aliquots $(250 \mu \mathrm{l})$ of AgNPs were diluted just before performing the aggregation kinetic experiment by adding ultrahigh purity water or buffer and different volumes of electrolytes $\left(1 \mathrm{M}\right.$ of $\mathrm{NaNO}_{3}$, and $3 \mathrm{mM}$ of $\left.\mathrm{Ca}\left(\mathrm{NO}_{3}\right)_{2}\right)$ to achieve a final volume of $10 \mathrm{~mL}$ for $\mathrm{UV}$-vis experiment. These dilutions resulted in a final concentration of 270.25 $\mu \mathrm{g} \mathrm{L}^{-1} \mathrm{AgNPs}$, and different concentration of electrolytes (40-260 $\mathrm{mM} \mathrm{NaNO}_{3}$ and 0.045$\left.1 \mathrm{mM} \mathrm{Ca}\left(\mathrm{NO}_{3}\right)_{2}\right)$ for aggregation kinetics analysis using UV-vis. The $\mathrm{pH}$ was measured at the end of each aggregation kinetic experiment and was in the range of 6.7 to 7.0 for buffer concentrations 0.25 to $1 \mathrm{mM}$ and in the range of 6-7 for buffer concentration of $0.05 \mathrm{mM}$ as well as for no buffer.

In order to account for the effect of calcium phosphate precipitation on the concentration of $\mathrm{Ca}^{2+}$ ions in solution and thus on AgNP aggregation kinetics, the speciation of calcium in solutions with different phosphate buffer concentrations was modeled using visual MINTEQ speciation model. Visual MITEQ is an equilibrium speciation model that can be used to calculate the equilibrium composition of dilute aqueous solutions. Input molar concentration for each component $\left(\mathrm{Ca}^{2+}, \mathrm{NO}_{3}{ }^{1-}, \mathrm{K}^{+}, \mathrm{PO}_{4}\right)$ is based on the concentration of these components in the aggregation kinetics experiment. The solution $\mathrm{pH}$ was maintained constant at 7.0 and hydroxyapatite was introduced as a possible solid phase. 
A stock suspension of SRFA (International Humic Substances Society, St. Paul, MN, USA) was prepared by dissolving $2 \mathrm{mg}$ of SRFA in $10 \mathrm{~mL}$ ultrahigh purity water, and the $\mathrm{pH}$ was adjusted to 7.0 by adding an appropriate amount of $\mathrm{NaOH}$. The suspension was then filtered through a $100 \mathrm{~nm}$ filter to remove any aggregated SRFA molecules. In order to prepare AgNP suspensions at the same concentrations (e.g. $270.25 \mu \mathrm{g} \mathrm{L}^{-1}$ ) as the experiments without SRFA, $0.8 \mathrm{~mL}$ of the stock suspension of SRFA was mixed with $2 \mathrm{~mL}$ of the stock suspension of the AgNPs and $3.2 \mathrm{~mL}$ of ultrahigh purity water giving a mixture of $5.4 \mathrm{mg} \mathrm{L}^{-1} \mathrm{AgNPs}$ and $20 \mathrm{mg} \mathrm{L}^{-}$ 1 of SRFA. Then the mixture was left for $24 \mathrm{~h}$ to reach equilibrium before performing any aggregation kinetic experiment. Just before performing the experiment, the mixture of AgNPs and SRFA was diluted by adding specific amount of buffer and different volume of electrolyte to reach a final volume of $10 \mathrm{ml}$ for UV-vis analysis. These dilutions resulted in a suspension of $270.25 \mu \mathrm{g} \mathrm{L}^{-1}$ AgNPs, $1 \mathrm{mg} \mathrm{L}^{-1}$ SRFA and different concentration of electrolytes for aggregation kinetic analysis by UV-vis.

Additionally, the effect of phosphate buffer on the aggregation behavior of cit-AgNPs was investigated by measuring the zeta potential of $\operatorname{AgNPs}\left(5.4 \mathrm{mgL}^{-1}\right)$ in the presence of different concentrations of buffer (0-2.5 mM). First, a stock solution of $9 \mathrm{mM}$ potassium phosphate monobasic was prepared and the $\mathrm{pH}$ was adjusted to 7.0 by adding aliquot $\mathrm{NaOH}$. Then, buffer stock solution was diluted to achieve different concentrations of buffer (0-5 mM). Aliquots $(2.5 \mathrm{ml})$ of AgNP stock suspension $\left(10.81 \mathrm{mg} \mathrm{L}^{-1}\right)$ were diluted in $2.5 \mathrm{ml}$ buffer $(0-5$ $\mathrm{mM}$ ) to achieve a final concentration of $5.40 \mathrm{mg} \mathrm{L}^{-1} \mathrm{AgNPs}$, and different concentrations of phosphate buffer (0-2.5 mM).

\section{Aggregation kinetics}

AgNP aggregation kinetics was performed by UV-vis according to the method described by Baalousha et al, (2013). Briefly, the aggregation rate constant (k) during the early stage of the aggregation is proportional to the rate of the decrease in the UV-vis at the specific plasmon resonance peak $(\lambda=396 \mathrm{~nm})$ of individual AgNPs. ${ }^{49}$ The slope of the loss in the UV-vis absorbance at $\lambda=396 \mathrm{~nm}$ within the first $10 \mathrm{~s}$ after mixing of AgNPs with the electrolytes was determined by fitting a linear correlation function. The short time $(10 \mathrm{sec})$ required to measure NM aggregation kinetics ensures that the reduction in the UV-vis absorbance is due to AgNP 
aggregation only as demonstrated in previous studies. ${ }^{7,} 50$ The attachment efficiency $(\alpha)$ or the inverse stability ratio (W) were calculated according to Eq. 1.

$$
\alpha=\frac{1}{W}=\frac{K_{\text {slow }}}{K_{\text {fast }}}
$$

Where $K_{\text {slow }}$ and $K_{\text {fast }}$ are the aggregation rate constant under reaction (RLA) and diffusion (DLA) limited aggregation regimes. $K_{\text {fast }}$ is calculated as the average of all aggregation rate constants measured under DLA regime under the same experimental conditions of NP and buffer concentrations. The RLA regime occurs when ionic strength is below the CCC, where NP interaction is governed by electrostatic energy barrier resulting from electrostatic double layer repulsion forces and van der Waals attractions forces. DLA occurs at ionic strength greater than CCC, where excess counter ions completely screen the surface charge and aggregation process is

only driven by NP diffusion. The CCC is the minimum concentration of electrolyte particularly sodium nitrate and calcium nitrate in this study, that is required to completely screen the NP surface charge. The attachment efficiencies under RLA and DLA regimes were plotted as a function of electrolyte concentration for different concentrations of buffer. Then, attachment efficiencies under RLA and DLA regimes were fitted by linear functions and their intersections represent the respective CCC, which is used in this study as a measure of NPs stability.

\section{Results and Discussion}

\subsection{Impact of phosphate buffer on the aggregation behavior of cit-AgNPs}

The UV-vis spectra of cit-AgNPs, after 10 min of mixing with different concentrations of $\mathrm{NaNO}_{3}$ buffered with different concentration of phosphate buffer $(0.05$ and $1.0 \mathrm{mM})$ are presented in Fig. 1a and b, respectively (full data set at 0, 0.05, 0.35, 0.5 and $1 \mathrm{mM}$ phosphate buffer concentrations is presented in Fig. S2, a-e). At low buffer concentration (0.05 mM, Fig. 1a), the increase in $\mathrm{NaNO}_{3}$ concentration results in the decrease in the UV-vis absorbance at 396 $\mathrm{nm}$, broadening of the UV-vis absorbance peak of the as-synthesized cit-AgNPs (centered on 396 $\mathrm{nm}$ ), and the formation of a second absorbance peak centered on ca. $600 \mathrm{~nm}$. These changes in the UV-vis spectra of cit-AgNPs indicates the loss of primary cit-AgNPs by aggregation in the presence of $\mathrm{NaNO}_{3}$ as observed elsewhere. ${ }^{7}$ It is well-known that cit-AgNPs are electrostatically stabilized, and that the increase in counter ion concentration (here $\mathrm{Na}^{+}$) results in surface charge screening, allowing AgNPs to stick together and aggregate. 
At high buffer concentrations (1 mM, Fig. 1b), a similar loss in the UV-vis absorbance at 396 is observed together with a formation of a broad second peak that extends to higher wavelengths compared with those at lower buffer concentrations (Fig 1a), potentially due to the formation of larger AgNP aggregates that absorb and scatter light at higher wavelengths. ${ }^{51}$ Furthermore, higher concentration of $\mathrm{NaNO}_{3}$ (ca. 100-260 mM, Fig. 1a) was required to induce aggregation of cit-AgNPs at lower buffer concentration $(0.05 \mathrm{mM})$ compared to those $(40-100$ $\mathrm{mM} \mathrm{NaNO}_{3}$, Fig. 1b) required to induce aggregation at higher buffer concentration. In general, the increase in buffer concentration in $0-1 \mathrm{mM}$ range (Fig. S2, a-e) results in increased loss of the UV-vis absorbance at $396 \mathrm{~nm}$ and further broadening of the UV-vis to higher wavelengths indicating increased aggregation of AgNPs with the increase in buffer concentration.

At the same concentration of $\mathrm{NaNO}_{3}$ (ca. $100 \mathrm{mM}$, Fig. S4a), the loss in the UV-vis absorbance at $396 \mathrm{~nm}$ increases with the increase in buffer concentration, which is accompanied by an increased broadening of the second peak toward higher wavelengths, indicating higher removal of primary NPs by increased aggregation at higher buffer concentrations. In other words, $\mathrm{NaNO}_{3}$ is more efficient in aggregating cit-AgNPs at higher buffer concentration than at lower buffer concentration. The increased cit-AgNPs aggregation with the increased phosphate buffer concentration is presumably due to the sorption of phosphate anions on the surface of $\operatorname{AgNPs}^{52}$, resulting in increased reduction of AgNP surface charge at higher buffer concentrations (see discussion below).

The UV-vis spectra of cit-AgNPs after 10 min of mixing with $\mathrm{Ca}\left(\mathrm{NO}_{3}\right)_{2}$ in different concentration of phosphate buffer $(0.05$ and $1.0 \mathrm{mM})$ are presented in Fig. 1c and d, respectively (full data set at 0, 0.05, 0.35, 0.5 and $1 \mathrm{mM}$ phosphate buffer concentrations is presented in Fig. $\mathrm{S} 3$ a-e). Similarly to $\mathrm{NaNO}_{3}$, the increase in $\mathrm{Ca}\left(\mathrm{NO}_{3}\right)_{2}$ results in increased loss of the UV-vis absorbance at $396 \mathrm{~nm}$, broadening of the absorbance peak of the as-synthesized cit-AgNPs, and the formation of a second peak centered on ca. $550 \mathrm{~nm}$, indicating the increased aggregation of cit-AgNPs with the increase in $\mathrm{Ca}\left(\mathrm{NO}_{3}\right)_{2}$ concentration. Furthermore, higher concentration of $\mathrm{Ca}\left(\mathrm{NO}_{3}\right)_{2}$ (ca. 0.25-0.8 mM, Fig. 1c) was required to induce aggregation of cit-AgNPs at lower buffer concentration $(0.05 \mathrm{mM})$ compared to higher buffer concentration $(0.045-0.25 \mathrm{mM}$ $\mathrm{Ca}\left(\mathrm{NO}_{3}\right)_{2}$, Fig. 1d). In general, the increase in buffer concentration in 0-1 mM range (Fig. S3 ae) results in increased loss of the UV-vis absorbance at $396 \mathrm{~nm}$ and further broadening of the 
UV-vis absorbance to higher wavelengths indicating increased aggregation of AgNPs with the increase in buffer concentration.

At the same concentration of $\mathrm{Ca}\left(\mathrm{NO}_{3}\right)_{2}$ (ca. $0.25 \mathrm{mM}$, Fig. S4b), the loss in the UV-vis absorbance at $396 \mathrm{~nm}$ increases with the increase in buffer concentration, which is accompanied by an increased broadening of the second peak toward higher wavelengths, indicating higher removal of primary AgNPs by increased aggregation at higher buffer concentrations. In other words, $\mathrm{Ca}\left(\mathrm{NO}_{3}\right)_{2}$ is more efficient in aggregating cit-AgNPs at higher buffer concentration (Fig. S4b) than at lower buffer concentration.

To measure AgNP aggregation kinetics' parameters (e.g. $\alpha$ and CCC), the loss of primary particles due to aggregation in the presence of $\mathrm{NaNO}_{3}$ and $\mathrm{Ca}\left(\mathrm{NO}_{3}\right)_{2}$ at different buffer concentrations was monitored by measuring the UV-vis absorbance at $\lambda=396$ (Fig. 2, full data set of all different buffer concentrations is presented in Fig. S5 and S6). The UV absorbance at $\lambda=396 \mathrm{~nm}$ follows a first order decrease at low electrolyte concentrations and a more rapid, higher order decrease at high electrolyte concentrations (Fig. 2a-d). In general, lower electrolyte concentrations ( $c a .40-120 \mathrm{NaNO}_{3}$, Fig. 2b and 0.045-0.25 mM Ca(NO$)_{2}$, Fig. 2d) were required to induce aggregation of cit-AgNPs at higher buffer concentration compared to lower buffer concentration (ca. 50-260 $\mathrm{NaNO}_{3}$, Fig. 2a and 0.25-0.9 mM Ca(NO$\left.)_{3}\right)_{2}$, Fig. 2c).

The attachment efficiencies of cit-AgNPs as a function of initial electrolyte concentration $\left(\mathrm{NaNO}_{3}\right.$ and $\left.\left(\mathrm{CaNO}_{3}\right)_{2}\right)$ in the presence of different buffer concentrations are presented in Fig. 3a and $b$, respectively. In the presence of phosphate anions, calcium precipitates forming hydroxyapatite resulting in a reduction of free calcium ions (Figure S7) available to induce Ag $\mathrm{NP}$ aggregation. Under the same initial $\mathrm{Ca}\left(\mathrm{NO}_{3}\right)_{2}$ concentration, the concentration of $\mathrm{Ca}^{2+}$ remaining in solution decreases with the increase in buffer concentration (Figure S7) due to the increased precipitation of hydroxyapatite. To account for reduction in $\mathrm{Ca}^{2+}$ concentration on AgNP aggregation kinetics with the increase in buffer concentration, the attachment efficiency curves are presented as a function of $\mathrm{Ca}^{2+}$ remaining in solution in Figure 3c. In general, the attachment efficiency curves as function of counter ion concentration show two aggregation regimes defined as reaction limited aggregation (RLA) and diffusion limited aggregation (DLA; Figure 3a-c). Fig. 3a-c shows that the attachment efficiency curves shift to the left (i.e. to lower counter ion concentrations) with the increased buffer concentration, suggesting that phosphate buffer enhances the aggregation of cit-AgNPs. At the same counter ion concentration under RLA 
regime, the attachment efficiency increases with the increase in buffer concentration (Fig. 3a-c). This behavior can be attributed to 1 ) added $\mathrm{Na}^{+}$and $\mathrm{K}^{+}$used to buffer and adjust the solution $\mathrm{pH}$, 2) sequestration of calcium ions by phosphate anions, and 3) reduction in AgNP surface charge due to sorption of phosphate anions on the surface of AgNPs.

The final concentration of $\mathrm{K}^{+}$added due to buffer solution and $\mathrm{Na}^{+}$added due to $\mathrm{pH}$ adjustment by $\mathrm{NaOH}$ are $<1$ and $0.4 \mathrm{mM}$, respectively for all solutions used in this study. These concentrations of $\mathrm{K}^{+}$and $\mathrm{Na}^{+}$are well below cit-AgNP aggregation threshold (ca. $>40 \mathrm{mM} \mathrm{Na}^{+}$, Fig 3a) and are much less than the shift in the attachment efficiency curves (ca. $100 \mathrm{mM}$ shift for 0.05 and $0.25 \mathrm{mM}$ phosphate buffer concentrations, Fig 3a). Therefore, the small concentrations of $\mathrm{K}^{+}$and $\mathrm{Na}^{+}$added from phosphate buffer and $\mathrm{NaOH}$ solutions cannot explain the differences in AgNP aggregation kinetics. Similarly, sequestration of $\mathrm{Ca}^{2+}$ ions is higher at higher buffer concentrations (Fig S7), resulting in more pronounced shift in the attachment efficiency curves when expressed as a function of $\mathrm{Ca}^{2+}$ remaining in solution (Fig 3c) compared to $\mathrm{Ca}\left(\mathrm{NO}_{3}\right)_{2}(\mathrm{Fig}$ $3 b)$. Thus, calcium sequestration by phosphate anions does not explain the differences in AgNP aggregation behavior. Consequently, the differences in AgNP aggregation behavior in the presence of phosphate buffer solution can be attributed to the higher adsorption of phosphate anions on the surface of cit-AgNPs at higher buffer concentrations, leading to a decrease in the surface charge (indicated by decrease in zeta potential) of cit-AgNPs at higher buffer concentrations (Fig. 4). Due to the low concentration of cit-AgNPs used in this study (270.25 $\mu \mathrm{g}$ $\mathrm{L}^{-1}$ ), it was not possible to measure the zeta potential of AgNPs in the presence of buffer using laser Doppler electrophoresis. Therefore, to demonstrate the impact of buffer concentration on the surface charge of cit-AgNPs, we measured the zeta potential of cit-AgNPs at higher buffer concentrations (0.5-2.5 mM) and higher cit-AgNP concentration (5.4 mg L $\left.{ }^{-1}\right)$. Cit-AgNPs are negatively charged without any buffer (zeta potential of $-41.7 \pm 2.0 \mathrm{mV}$ ). The addition of phosphate anions results in a decrease in the zeta potential of cit-AgNPs, which can be attributed to the sorption/complexation of the phosphate anions on AgNP surfaces, ${ }^{52,53}$ due to the high affinity of phosphate anions to silver $\left(K_{s p}=8.89 \times 10^{-17} \mathrm{M}\right){ }^{54}$

The zeta potential of cit-AgNPs decreases rapidly at low buffer concentrations ( $c a$. from $41.7 \pm 2.0 \mathrm{mV}$ to $-30.4 \pm 0.7 \mathrm{mV}$ for an increase in buffer concentration from 0 to $1 \mathrm{mM}$ ), followed by a slower decrease at higher buffer concentrations (ca. 1-2.5 mM; Fig. 4). The zeta potential of AgNPs tends to a stable value of $c a .-29 \pm 1.0 \mathrm{mV}$ at higher buffer concentrations (calculated as 
the average and standard deviation of the zeta potential measured at buffer concentration in the range of 1.0-2.5 mM). This is likely due to the saturation of the surface of AgNPs with phosphate anions at higher buffer concentrations. ${ }^{55}$

The CCC as a function of phosphate buffer concentration decreases with the increase in buffer concentration (Fig. 5a and 5b), which can be attributed to the reduction in the zeta potential of AgNPs due to the sorption of phosphate anions on the surface of AgNPs. The CCC decreases rapidly at low buffer concentrations and tends to a stable value with the increase in buffer concentration (ca. $90.9 \mathrm{mM} \mathrm{NaNO}_{3}$, Fig. 5a, $0.10 \mathrm{mM}$ intial $\mathrm{Ca}\left(\mathrm{NO}_{3}\right)_{2}$, Fig. 5b, $0.017 \mathrm{mM}$ free $\mathrm{Ca}^{2+}$, Fig. 5c). This behavior is in good agreement with the zeta potential reduction due to the sorption of phosphate anions on the surface of AgNPs (Fig. 4). Therefore, the reduction in the CCC with the increase in buffer concentration can be attributed to the decrease in zeta potential. The tendency in CCC to a stable value at high buffer concentrations can be attributed to the saturation of AgNPs surface with phosphate anions at higher buffer concentrations. The decrease in the CCC for citrate AgNPs with the increase in phosphate buffer concentration is in good agreement with the reported decrease in the CCC for charge stabilized-AgNPs with the increase in carbonate buffer concentration ${ }^{29,} 30$. For instance, the CCC of $\mathrm{Na}^{+}$for charge stabilized-AgNPs decreases from approximately $150 \mathrm{mM} \mathrm{Na}{ }^{+}$in the absence of buffer to approximately $25 \mathrm{mM} \mathrm{Na}^{+}$at higher carbonate buffer concentrations $\left(c a .>0.05 \mathrm{mM} \mathrm{NaHCO}_{3}\right)^{29}$.

Herein, cit-AgNPs aggregation can be explained by both chemical and physical interactions. Phosphate anions can replace the citrate coating and bind to the NP surface through its oxygen atoms, resulting in phosphate coated AgNPs. ${ }^{52}$ Aggregation of phosphate coated AgNPs takes place through physical surface charge screening by counter ions $\left(\mathrm{Na}^{+}\right.$and $\left.\mathrm{Ca}^{2+}\right)$ according to DLVO theory. ${ }^{7}$

\section{Aggregation impacted by fulvic acid}

The UV-vis spectra of cit-AgNPs 10 minutes after interaction with phosphate buffer in the presence of $1 \mathrm{mgL}^{-1} \mathrm{SRFA}$ show a decrease in the UV-vis absorbance at $\lambda=396 \mathrm{~nm}$ concurrent with a broadening of the peak with $\mathrm{NaNO}_{3}$, and formation of a second peak with $\mathrm{Ca}\left(\mathrm{NO}_{3}\right)_{2}$, which can be attributed to the aggregation of primary cit-AgNPs (Fig. 6, a-d). At the same $\mathrm{NaNO}_{3}$ and $\mathrm{Ca}\left(\mathrm{NO}_{3}\right)_{2}$ concentrations, primary $\mathrm{NP}$ peak at $396 \mathrm{~nm}$ decays to higher absorbance and peak shoulder is narrower in the presence of SRFA compared to those in the absence of SRFA (Fig. S7a and b). For example, cit-AgNP peak at $396 \mathrm{~nm}$ in $1 \mathrm{mM}$ buffer and 
$100 \mathrm{mM} \mathrm{NaNO} 3$ decays to higher absorbance ( 0.24, Fig. S7a) in the presence of SRFA compared to the absence of SRFA $(\sim 0.08$, Fig. S7a) and the peak is broader in the absence of SRFA suggesting that SRFA increase the stability of cit-AgNPs against cation induced aggregation. Similarly, cit-AgNP peak at $396 \mathrm{~nm}$ in $1 \mathrm{mM}$ buffer and $0.25 \mathrm{mM} \mathrm{Ca}\left(\mathrm{NO}_{3}\right)_{2} \mathrm{mM}$ decays to higher absorbance $(\sim 0.30$, Fig. S7b) in the presence of SRFA compared to the absence of SRFA ( 0.15, Fig. S7b) and the peak is broader in the absence of SRFA suggesting that SRFA increase the stability of cit-AgNPs against cation induced aggregation. However, SRFA does not entirely eliminate the impact of phosphate anions on the aggregation of cit-AgNPs.

The attachment efficiency of cit-AgNPs in the presence of SRFA and at different phosphate buffer concentrations is presented in Fig. $7 \mathrm{a}$ and $\mathrm{b}$ for $\mathrm{NaNO}_{3}$ and $\mathrm{Ca}\left(\mathrm{NO}_{3}\right)_{2}$. Within the RLA regime, at the same electrolyte concentration, the attachment efficiency increase with the increase in buffer concentration, suggesting that the increased buffer concentration reduced the stability of cit-AgNPs, presumably due to the sorption of phosphate anions on the surface of cit-AgNPs in the presence of SRFA. The CCC shifted to lower counter ion concentrations $\left(157.7 \pm 4.4 \mathrm{mM} \mathrm{NaNO}_{3}\right.$ and $\left.1.5 \pm 0.03 \mathrm{Ca}\left(\mathrm{NO}_{3}\right)_{2}\right)$ at higher buffer concentration compared to the $\mathrm{CCC}\left(265.3 \pm 2.5 \mathrm{mM} \mathrm{NaNO}_{3}\right.$ and $\left.1.8 \pm 0.21 \mathrm{mM} \mathrm{Ca}\left(\mathrm{NO}_{3}\right)_{2}\right)$ at lower buffer concentration (Fig. 7 a and b, Table 1). It is worth noting that in the case of $\mathrm{Ca}^{2+}$ counter ions (Fig. 7b), the attachment efficiency does not show a clear separation between the RLA and DLA regimes, and the attachment efficiency reaches values $>1.0$ at high $\mathrm{Ca}^{2+}$ concentration. This behavior can be attributed to inter-particle bridging by humic acid aggregates as observed elsewhere. ${ }^{27}$ Enhanced aggregation has been attributed to inter-particle bridging of NPs by humic acid aggregates which form through the complex formation between humic acid macromolecules with $\mathrm{Ca}^{2+}$ ions. ${ }^{56}$

Furthermore, at the same concentration of buffer, the CCC shifted to higher electrolyte concentration in the presence of SRFA (Fig. 7a and b) compared to the CCC values in the absence of SRFA (Fig. 3 and Table 1). It has been demonstrated that fulvic acid replaces citrate coating and form a surface coating on AgNPs and increase their stability. ${ }^{57}$ Several studies have demonstrated the shift in CCC to higher counter ion concentrations in the presence of SRFA. ${ }^{1,27}$, ${ }^{38}$ However, SRFA did not completely inhibit surface charge screening and NP aggregation by $\mathrm{NaNO}_{3}$ and $\mathrm{Ca}\left(\mathrm{NO}_{3}\right)_{2}$ electrolytes. ${ }^{7,} 58$ Additionally, SRFA did not prevent the reduction in AgNP stability due to their interaction with phosphate anions.

\section{Environmental Implications and Conclusions}


Buffers have been widely used in environmental and toxicological studies to maintain constant $\mathrm{pH}$ values without investigating the impact of the buffer on the stability of the NPs. Here, we systematically investigated the impact of phosphate buffer concentration (as an example) and SRFA on the aggregation kinetics of cit-AgNPs by $\mathrm{NaNO}_{3}$ and $\mathrm{Ca}\left(\mathrm{NO}_{3}\right)_{2}$ by measuring the aggregation kinetics of cit-AgNPs at different phosphate buffer concentrations (ca. 0 to $1.0 \mathrm{mM}$ ). The increase in buffer resulted in a decrease in the CCC both in the presence and absence of SRFA. The CCC tends to a constant value at ca. $1.0 \mathrm{mM}$ phosphate buffer concentration for the concentrations of cit-AgNPs used in this study $\left(270.25 \mu \mathrm{g} \mathrm{L}^{-1}\right)$. The buffer concentration required to reach a stable CCC depends on the concentration of AgNPs, and decrease with the decrease in NP concentrations as lower buffer anions concentration will be required to fully coat the surface of AgNPs.

The majority of NP aggregation kinetic studies has focused on the role of counter ions (ca. $\left.\mathrm{Na}^{+}, \mathrm{Ca}^{2+}, \mathrm{Mg}^{2+}\right)^{27,59,60}$, and few studies investigated the impact of anions such as carbonates and phosphates on NP aggregation. ${ }^{61} 762$ Nonetheless, buffers (e.g. carbonate, phosphate, MOPS, etc.) are widely used in aggregation kinetic studies to maintain a constant pH. ${ }^{12}$ These studies reported different CCC values. For instance, El Badawy et al. $2012^{23}$ reported higher $\mathrm{CCC}$ (ca. $70 \mathrm{mM} \mathrm{NaNO} 3$ and $5 \mathrm{mM} \mathrm{Ca}\left(\mathrm{NO}_{3}\right)_{2}$ ) for $58 \mathrm{~nm}$ cit-AgNPs compared to the study by $\mathrm{Li} 2011\left(70 \mathrm{mM} \mathrm{NaNO}{ }_{3}\right.$ and $\left.5 \mathrm{mM} \mathrm{Ca}\left(\mathrm{NO}_{3}\right)_{2}\right)$ for $64 \mathrm{~nm}$ cit-AgNPs ${ }^{26}$. Based on our findings, the lower CCC values reported in Li et al. (2011) compared to those reported by Badawy et al. $2012^{23}$ can be attributed (at least partially) to the higher carbonate buffer concertation used in the former study.

Considering the lower expected environmental concentrations of AgNPs (0.01-10 $\mu \mathrm{g} \mathrm{L}$ $\left.{ }^{1}\right)^{4,5}$ compared to those investigated in this study $\left(270.25 \mu \mathrm{g} \mathrm{L}^{-1}\right)$, it is likely that at lower NP concentrations, the $\mathrm{CCC}$ will tend to a constant value at lower phosphate anion concentrations as lower phosphate anion concentrations will be required to saturate the surface of AgNPs. Considering the higher NP concentrations typically studied in the literature e.g. $\left(\mathrm{mg} \mathrm{L}^{-1}\right.$; Table $\mathrm{S} 1$ ), it is likely that studies performed at high NP concentration underestimates the attachment efficiencies and CCC, and these values need to be considered carefully.

\section{Acknowledgment}

This work was supported by the National Science Foundation (NSF, 1437307). We would like to acknowledge the SmartState Center for Environmental Nanoscience and Risk (CENR) 
and the Arnold School of Public Health, both at the University of South Carolina for financial support.

\section{List of abbreviations}

NPs: nanoparticles

AgNPs: silver nanoparticles

SRFA: Suwannee River Fulvic Acid

CCC: critical coagulation concentration

$\alpha$ : attachment efficiency

$\mathrm{W}$ : stability ratio

RLA: reaction limited aggregation

DLA: diffusion limited aggregation

NOM: natural organic matter

DLS: dynamic light scattering

EPM: electrophoretic mobility 

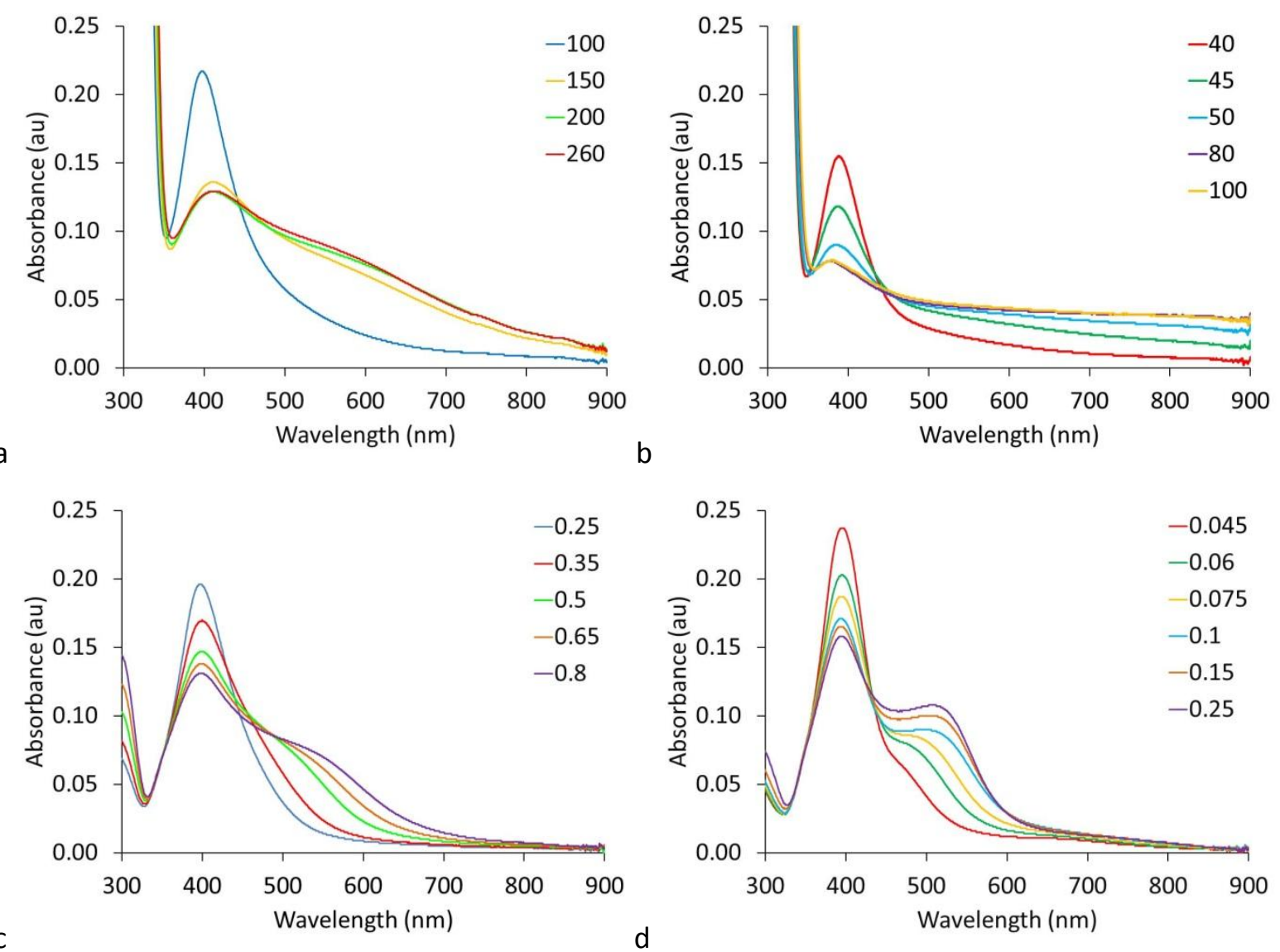

Fig. 1. UV-vis spectra of cit-AgNPs $\left(270.25 \mu \mathrm{g} \mathrm{L}^{-1}\right)$ collected $10 \mathrm{~min}$ after mixing with different concentrations of $\mathrm{NaNO}_{3}\left(a\right.$ and $b$ ) and $\mathrm{Ca}\left(\mathrm{NO}_{3}\right)_{2}$ (c and d) in different concentrations of potassium phosphate monobasic buffer $(\mathrm{pH} 7.0)$ : (a, and c) $0.05 \mathrm{mM}$, and (b, and d) $1 \mathrm{mM}$. Figure legend represents the electrolyte concentrations 

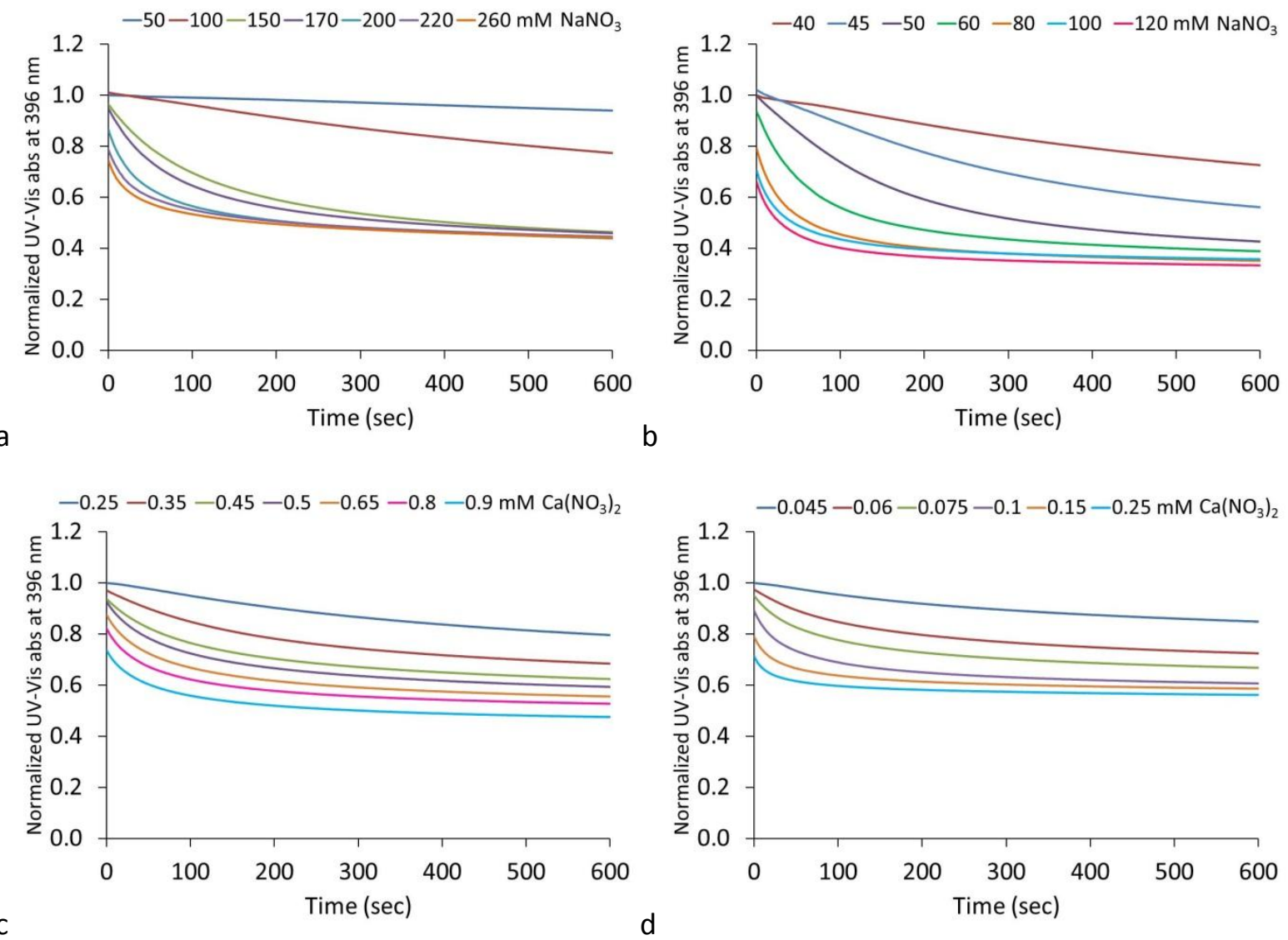

Fig. 2. Evolution of the UV-vis absorbance at $\lambda_{396}$ of cit-AgNPs $\left(270.25 \mu \mathrm{g} \mathrm{L}^{-1}\right)$ as a function of time immediately after mixing with different concentrations of $\mathrm{NaNO}_{3}\left(\mathrm{a}\right.$ and b) and $\mathrm{Ca}\left(\mathrm{NO}_{3}\right)_{2}$ ( $\mathrm{c}$ and d) in different concentrations of buffer ( $\mathrm{pH}$ 7.0): ( $\mathrm{a}$, and c) $0.05 \mathrm{mM}$, and (b, and d) $1 \mathrm{mM}$ 

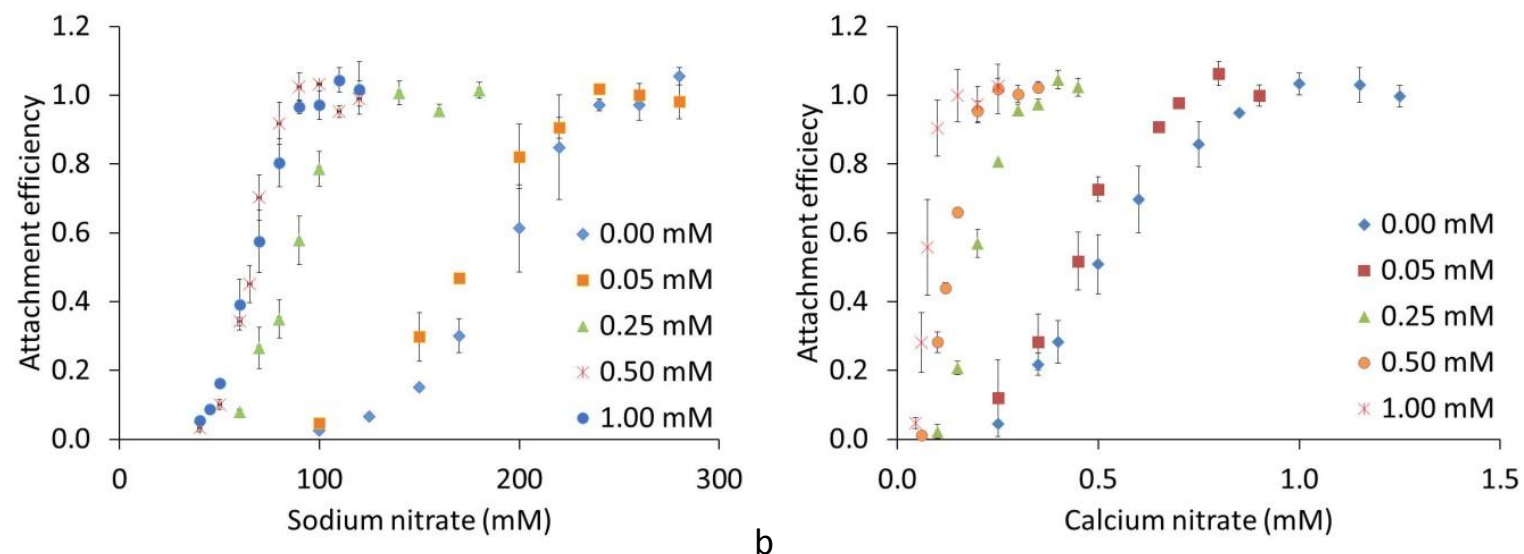

a

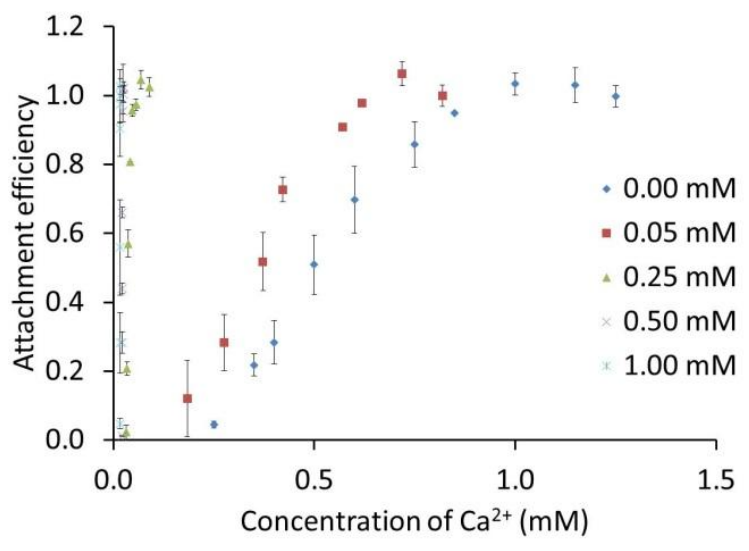

Fig. 3. Attachment efficiency of cit-AgNPs $\left(270.25 \mu \mathrm{g} \mathrm{L}^{-1}\right)$ at different concentrations of phosphate buffer reacted with: (a) $\mathrm{NaNO}_{3}$, (b) $\mathrm{Ca}\left(\mathrm{NO}_{3}\right)_{2}$, and (c) $\mathrm{Ca}^{2+}$ remaining in solution. All experiments were performed at $\mathrm{pH}$ 7.0. Figure legend represents potassium phosphate monobasic buffer concentration 


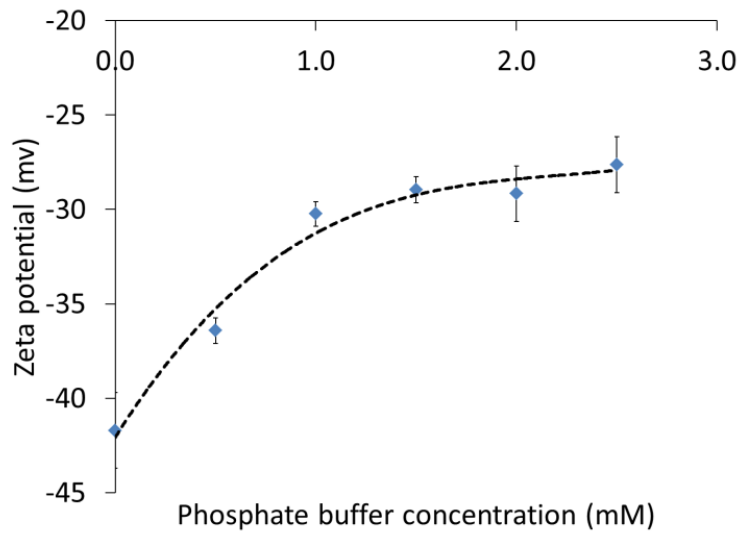

Fig. 4. Zeta potential of cit-AgNPs as a function of potassium phosphate monobasic buffer concentration. Measurements were performed at higher NP concentration (5.4 $\mathrm{mg} \mathrm{L}^{-1}$ ). Dotted line is used to guide the reader eye. 

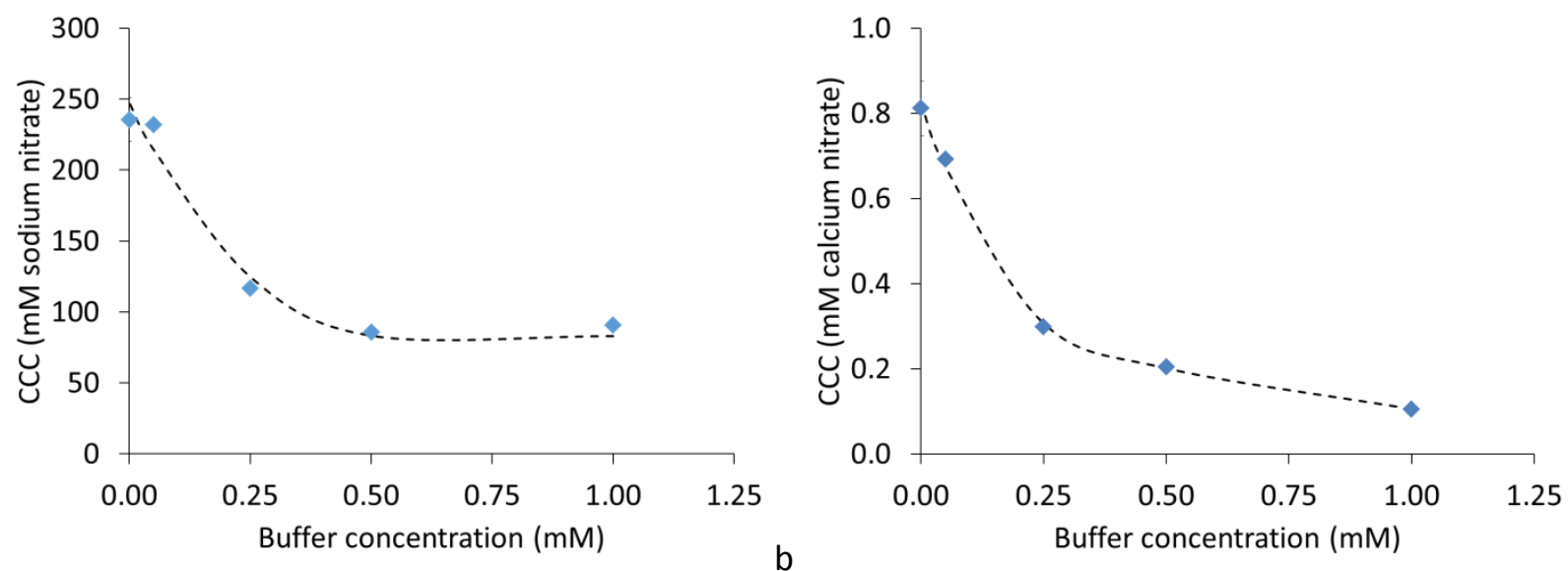

a

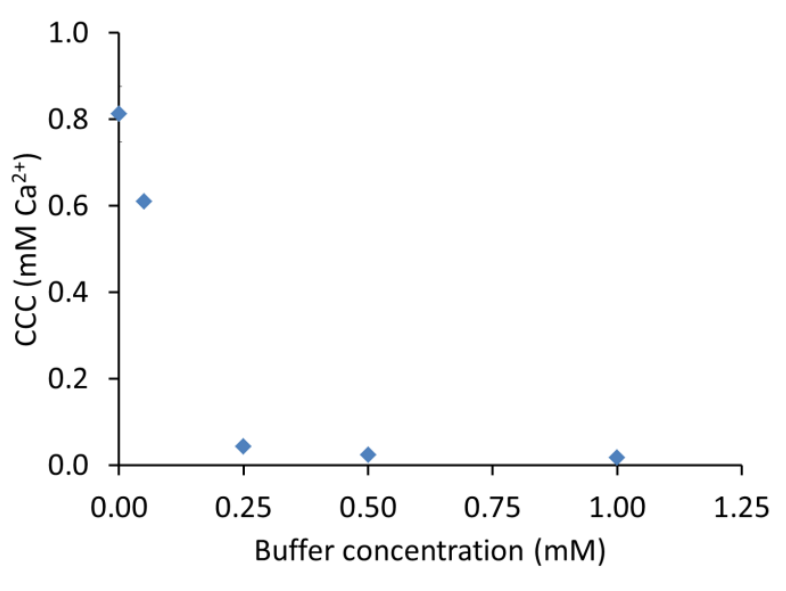

Fig. 5. Critical coagulation concentration of cit-AgNPs $\left(270.25 \mu \mathrm{g} \mathrm{L^{-1 }}\right)$ as a function of phosphate buffer concentration in the presence of monovalent and divalent electrolytes (a) $\mathrm{NaNO}_{3}$, (b) $\mathrm{Ca}\left(\mathrm{NO}_{3}\right)_{2}$ and (c) $\mathrm{Ca}^{2+}$ remaining in solution following precipitation of hydroxyapatite. Dotted line is used to guide the reader eye. 

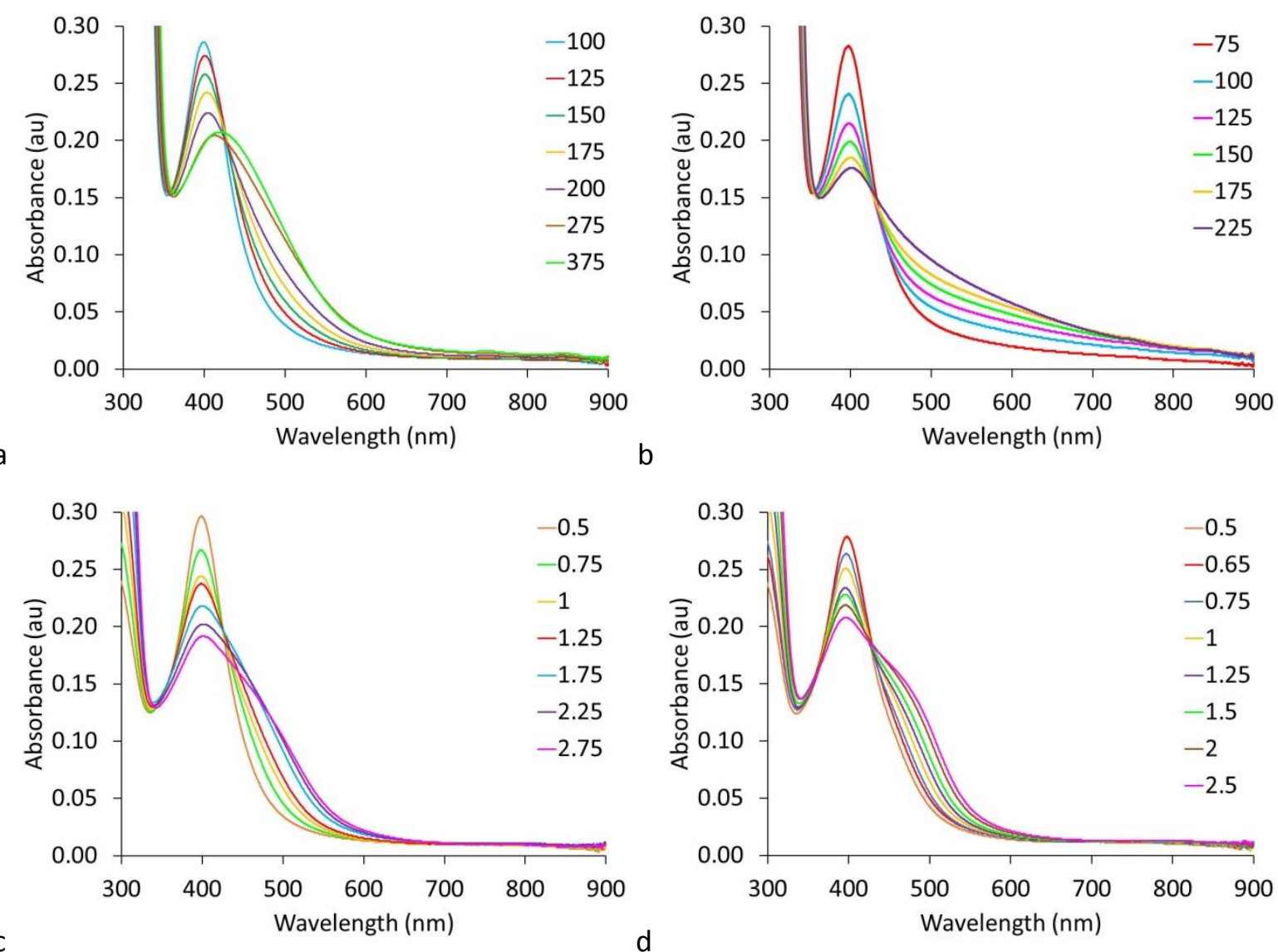

Fig. 6. UV-vis spectra of cit-AgNPs $\left(270.25 \mu \mathrm{g} \mathrm{L}^{-1}\right)$ mixed with1 $\mathrm{mgL}^{-1}$ Suwannee River fulvic acid (SRFA) collected 10 min after mixing with different concentrations of $\mathrm{NaNO}_{3}\left(a\right.$ and $b$ ) and $\mathrm{Ca}\left(\mathrm{NO}_{3}\right)_{2}$ (c and d) in different concentrations of buffer ( $\mathrm{pH}$ 7.0): ( $a$, and c) $0.05 \mathrm{mM}$, and (b, and d) $1 \mathrm{mM}$. Figure legend represents the electrolyte concentrations 

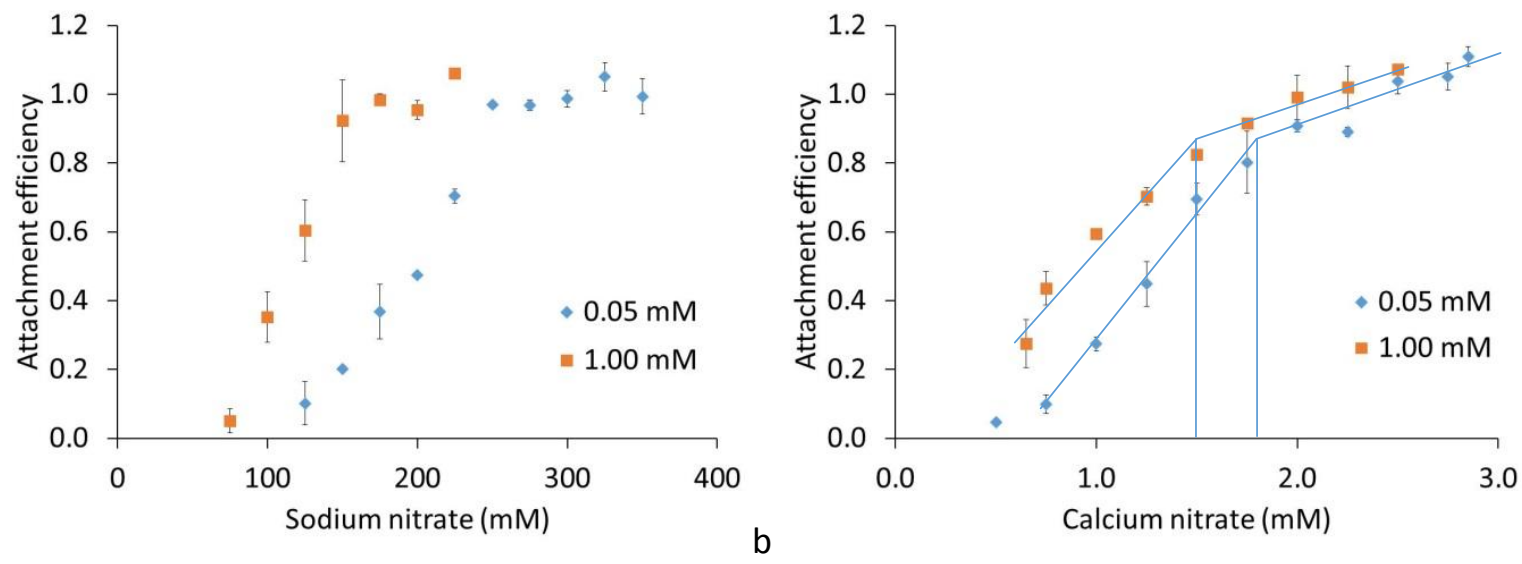

Fig. 7. Attachment efficiency of cit-AgNPs $\left(270.25 \mu \mathrm{g} \mathrm{L}^{-1}\right)$ at different concentrations of phosphate buffer reacted with: (a) $\mathrm{NaNO}_{3}$, (b) $\mathrm{Ca}\left(\mathrm{NO}_{3}\right)_{2}$ in the presence of SRFA (1 mg L-1)

Table 1. CCC values in the presence and absence of SRFA

\begin{tabular}{|c|c|c|c|}
\hline $\begin{array}{c}\text { Buffer Concentration } \\
(m M)\end{array}$ & Electrolyte & $\begin{array}{c}\text { CCC in the presence of } \\
\text { SRFA (mM) }\end{array}$ & $\begin{array}{c}\text { CCC in the absence of } \\
\text { SRFA (mM) }\end{array}$ \\
\hline 0.05 & $\mathrm{NaNO}_{3}$ & $265.3 \pm 2.5$ & $232.0 \pm 1.4$ \\
\hline 1.00 & $\mathrm{NaNO}_{3}$ & $157.7 \pm 4.4$ & $90.9 \pm 2.2$ \\
\hline 0.05 & $\mathrm{Ca}\left(\mathrm{NO}_{3}\right)_{2}$ & $1.8 \pm 0.21$ & $0.7 \pm 0.001$ \\
\hline 1.00 & $\mathrm{Ca}\left(\mathrm{NO}_{3}\right)_{2}$ & $1.5 \pm 0.03$ & $0.1 \pm 0.008$ \\
\hline
\end{tabular}




\section{References}

1. Wijnhoven, S. W. P.; Peijnenburg, W.; Herberts, C. A.; Hagens, W. I.; Oomen, A. G.; Heugens, E. H. W.; Roszek, B.; Bisschops, J.; Gosens, I.; Van de Meent, D.; Dekkers, S.; De Jong, W. H.; Van Zijverden, M.; Sips, A.; Geertsma, R. E., Nano-silver - a review of available data and knowledge gaps in human and environmental risk assessment. Nanotoxicology 2009, 3, (2), 109-U78.

2. Benn, T. M.; Westerhoff, P., Nanoparticle Silver Released into Water from Commercially Available Sock Fabrics. Environmental Science \& Technology 2008, 42, (11), 4133-4139.

3. Kaegi, R.; Sinnet, B.; Zuleeg, S.; Hagendorfer, H.; Mueller, E.; Vonbank, R.; Boller, M.; Burkhardt, M., Release of silver nanoparticles from outdoor facades. Environmental Pollution 2010, 158, (9), 29002905.

4. Gottschalk, F.; Sonderer, T.; Scholz, R. W.; Nowack, B., Modeled Environmental Concentrations of Engineered Nanomaterials (TiO2, $\mathrm{ZnO}, \mathrm{Ag}, \mathrm{CNT}$, Fullerenes) for Different Regions. Environmental Science \& Technology 2009, 43, (24), 9216-9222.

5. Gottschalk, F.; Sun, T.; Nowack, B., Environmental concentrations of engineered nanomaterials: Review of modeling and analytical studies. Environmental Pollution 2013, 181, 287-300.

6. $\quad$ Loza, K.; Diendorf, J.; Sengstock, C.; Ruiz-Gonzalez, L.; Gonzalez-Calbet, J. M.; Vallet-Regi, M.; Koller, M.; Epple, M., The dissolution and biological effects of silver nanoparticles in biological media. Journal of Materials Chemistry B 2014, 2, (12), 1634-1643.

7. Baalousha, M.; Nur, Y.; Römer, I.; Tejamaya, M.; Lead, J. R., Effect of monovalent and divalent cations, anions and fulvic acid on aggregation of citrate-coated silver nanoparticles. Science of The Total Environment 2013, 454-455, 119-131.

8. Levard, C.; Hotze, E. M.; Colman, B. P.; Dale, A. L.; Truong, L.; Yang, X. Y.; Bone, A. J.; Brown, G. E.; Tanguay, R. L.; Di Giulio, R. T.; Bernhardt, E. S.; Meyer, J. N.; Wiesner, M. R.; Lowry, G. V., Sulfidation of Silver Nanoparticles: Natural Antidote to Their Toxicity. Environmental Science \& Technology 2013, 47, (23), 13440-13448.

9. Kaegi, R.; Voegelin, A.; Ort, C.; Sinnet, B.; Thalmann, B.; Krismer, J.; Hagendorfer, H.; Elumelu, M.; Mueller, E., Fate and transformation of silver nanoparticles in urban wastewater systems. Water Research 2013, 47, (12), 3866-3877.

10. Lowry, G. V.; Gregory, K. B.; Apte, S. C.; Lead, J. R., Transformations of Nanomaterials in the Environment. Environmental Science \& Technology 2012, 46, (13), 6893-6899.

11. Peijnenburg, W. J. G. M.; Baalousha, M.; Chen, J.; Chaudry, Q.; Von Der Kammer, F.; Kuhlbusch, T. A. J.; Lead, J.; Nickel, C.; Quik, J. T. K.; Renker, M., A review of the properties and processes determining the fate of engineered nanomaterials in the aquatic environment. Critical Reviews in Environmental Science and Technology 2015, (just-accepted), 00-00.

12. Stemig, A. M.; Do, T. A.; Yuwono, V. M.; Arnold, W. A.; Penn, R. L., Goethite nanoparticle aggregation: effects of buffers, metal ions, and 4-chloronitrobenzene reduction. Environmental Science: Nano 2014, 1, (5), 478-487.

13. Mirshahghassemi, S.; Lead, J. R., Oil Recovery from Water under Environmentally Relevant Conditions Using Magnetic Nanoparticles. Environmental Science \& Technology 2015, 49, (19), 1172911736.

14. Mirshahghassemi, S.; Cai, B.; Lead, J. R., Evaluation of polymer-coated magnetic nanoparticles for oil separation under environmentally relevant conditions: effect of ionic strength and natural organic macromolecules. Environmental Science: Nano 2016.

15. Li, M.; Pokhrel, S.; Jin, X.; Mädler, L.; Damoiseaux, R.; Hoek, E. M. V., Stability, bioavailability, and bacterial toxicity of $\mathrm{ZnO}$ and iron-doped $\mathrm{ZnO}$ nanoparticles in aquatic media. Environmental science \& technology 2010, 45, (2), 755-761. 
16. Dale, A. L.; Lowry, G. V.; Casman, E. A., Much ado about [small alpha]: reframing the debate over appropriate fate descriptors in nanoparticle environmental risk modeling. Environmental Science: Nano 2015, 2, (1), 27-32.

17. Nowack, B.; Bucheli, T. D., Occurrence, behavior and effects of nanoparticles in the environment. Environmental Pollution 2007, 150, (1), 5-22.

18. Chen, K. L.; Elimelech, M., Aggregation and Deposition Kinetics of Fullerene (C60) Nanoparticles. Langmuir 2006, 22, (26), 10994-11001.

19. Baveye, P.; Laba, M., Aggregation and toxicology of titanium dioxide nanoparticles. Environmental Health Perspectives 2008, 116, (4), A152-A152.

20. Crane, M.; Handy, R. D.; Garrod, J.; Owen, R., Ecotoxicity test methods and environmental hazard assessment for engineered nanoparticles. Ecotoxicology 2008, 17, (5), 421-437.

21. Peijnenburg, W. J. G. M.; Baalousha, M.; Chen, J.; Chaudry, Q.; Von der kammer, F.; Kuhlbusch, T. A. J.; Lead, J.; Nickel, C.; Quik, J. T. K.; Renker, M.; Wang, Z.; Koelmans, A. A., A Review of the Properties and Processes Determining the Fate of Engineered Nanomaterials in the Aquatic Environment. Critical Reviews in Environmental Science and Technology 2015, 45, (19), 2084-2134.

22. Nur, Y.; Lead, J. R.; Baalousha, M., Evaluation of charge and agglomeration behavior of TiO2 nanoparticles in ecotoxicological media. Science of The Total Environment 2015, 535, 45-53.

23. El Badawy, A. M.; Scheckel, K. G.; Suidan, M.; Tolaymat, T., The impact of stabilization mechanism on the aggregation kinetics of silver nanoparticles. Science of the total environment 2012, 429, 325-331.

24. Liu, X.; Wazne, M.; Han, Y.; Christodoulatos, C.; Jasinkiewicz, K. L., Effects of natural organic matter on aggregation kinetics of boron nanoparticles in monovalent and divalent electrolytes. Journal of Colloid and Interface Science 2010, 348, (1), 101-107.

25. Praetorius, A.; Tufenkji, N.; Goss, K.-U.; Scheringer, M.; von der Kammer, F.; Elimelech, M., The road to nowhere: equilibrium partition coefficients for nanoparticles. Environmental Science: Nano 2014, 1, (4), 317-323.

26. Li, X.; Lenhart, J. J.; Walker, H. W., Aggregation Kinetics and Dissolution of Coated Silver Nanoparticles. Langmuir 2012, 28, (2), 1095-1104.

27. Huynh, K. A.; Chen, K. L., Aggregation Kinetics of Citrate and Polyvinylpyrrolidone Coated Silver Nanoparticles in Monovalent and Divalent Electrolyte Solutions. Environmental Science \& Technology 2011, 45, (13), 5564-5571.

28. Badawy, A. M. E.; Luxton, T. P.; Silva, R. G.; Scheckel, K. G.; Suidan, M. T.; Tolaymat, T. M., Impact of environmental conditions ( $\mathrm{pH}$, ionic strength, and electrolyte type) on the surface charge and aggregation of silver nanoparticles suspensions. Environmental science \& technology 2010, 44, (4), 1260 1266.

29. Afshinnia, K.; Sikder, M.; Cai, B.; Baalousha, M., Effect of nanomaterial and media physicochemical properties on Ag NM aggregation kinetics. Journal of Colloid and Interface Science 2017, 487, 192-200.

30. Baalousha, M., Effect of nanomaterial and media physicochemical properties on nanomaterial aggregation kinetics. Nanolmpact. http://dx.doi.org/10.1016/j.impact.2016.10.00531. Baalousha, M., Aggregation and disaggregation of iron oxide nanoparticles: influence of particle concentration, $\mathrm{pH}$ and natural organic matter. Science of the total Environment 2009, 407, (6), 2093-2101.

32. Petosa, A. R.; Jaisi, D. P.; Quevedo, I. R.; Elimelech, M.; Tufenkji, N., Aggregation and deposition of engineered nanomaterials in aquatic environments: role of physicochemical interactions.

Environmental science \& technology 2010, 44, (17), 6532-6549.

33. Piccapietra, F.; Sigg, L.; Behra, R., Colloidal stability of carbonate-coated silver nanoparticles in synthetic and natural freshwater. Environmental science \& technology 2011, 46, (2), 818-825. 
34. Buchholz, A.; Laskov, C.; Haderlein, S. B., Effects of Zwitterionic buffers on sorption of ferrous iron at goethite and its oxidation by CCl4. Environ Sci Technol 2011, 45, (8), 3355-60.

35. Loosli, F.; Le Coustumer, P.; Stoll, S., Effect of electrolyte valency, alginate concentration and pH on engineered TiO(2) nanoparticle stability in aqueous solution. Sci Total Environ 2015, 535, 28-34.

36. Loosli, F.; Le Coustumer, P.; Stoll, S., Impact of alginate concentration on the stability of agglomerates made of $\mathrm{TiO} 2$ engineered nanoparticles: Water hardness and pH effects. Journal of Nanoparticle Research 2015, 17, (1), 44.

37. Li, X.; Lenhart, J. J.; Walker, H. W., Dissolution-accompanied aggregation kinetics of silver nanoparticles. Langmuir 2010, 26, (22), 16690-16698.

38. Baalousha, M. A., K.; Sikder, M.; Cai, B., Effect of nanomaterial and media physicochemical properties on Ag NM aggregation kinetics. Environ. Sci. Nano. (Submitted) 2016

39. Baalousha, M.; Nur, Y.; Romer, I.; Tejamaya, M.; Lead, J. R., Effect of monovalent and divalent cations, anions and fulvic acid on aggregation of citrate-coated silver nanoparticles. Sci Total Environ 2013, 454-455, 119-31.

40. Dale, A. L.; Casman, E. A.; Lowry, G. V.; Lead, J. R.; Viparelli, E.; Baalousha, M., Modeling Nanomaterial Environmental Fate in Aquatic Systems. Environmental Science \& Technology 2015, 49, (5), 2587-2593.

41. Park, K.; Lee, Y., The stability of citrate-capped silver nanoparticles in isotonic glucose solution for intravenous injection. Journal of Toxicology and Environmental Health, Part A 2013, 76, (22), 12361245.

42. Hudson, J. J.; Taylor, W. D.; Schindler, D. W., Phosphate concentrations in lakes. Nature 2000, 406, (6791), 54-56.

43. Brain, R. T.; Kay, H. D.; Marshall, P. G., Observations on phosphates in blood and on the urinary excretion of phosphates. Biochemical Journal 1928, 22, (3), 628.

44. Harvey, C. J.; LeBouf, R. F.; Stefaniak, A. B., Formulation and stability of a novel artificial human sweat under conditions of storage and use. Toxicology in vitro : an international journal published in association with BIBRA 2010, 24, (6), 1790-6.

45. Navolotskaya, D. V.; Toh, H. S.; Batchelor-McAuley, C.; Compton, R. G., Voltammetric Study of the Influence of Various Phosphate Anions on Silver Nanoparticle Oxidation. ChemistryOpen 2015, 4, (5), 595-599.

46. White, P. J.; Hammond, J. P., The Sources of Phosphorus in the Waters of Great Britain All rights reserved. No part of this periodical may be reproduced or transmitted in any form or by any means, electronic or mechanical, including photocopying, recording, or any information storage and retrieval system, without permission in writing from the publisher. Journal of Environmental Quality 2009, 38. 47. STORET, 1995. STOrage and RETrieval. The US EPA Water Quality Database. US Environmental Protection Agency, Office of Water.

48. Romer, I.; White, T. A.; Baalousha, M.; Chipman, K.; Viant, M. R.; Lead, J. R., Aggregation and dispersion of silver nanoparticles in exposure media for aquatic toxicity tests. In J Chromatogr A, 2011 Elsevier B.V: Netherlands, 2011; Vol. 1218, pp 4226-33.

49. Moskovits, M.; Vlckova, B., Adsorbate-induced silver nanoparticle aggregation kinetics. Journal of Physical Chemistry B 2005, 109, (31), 14755-14758.

50. Baalousha, M.; Afshinnia, K.; Gibson, I.; Merrifield, R., The concentration-dependent Aggregation of Citrate Coated Ag NPs Induced by Cystine. In 2016.

51. Paramelle, D.; Sadovoy, A.; Gorelik, S.; Free, P.; Hobley, J.; Fernig, D. G., A rapid method to estimate the concentration of citrate capped silver nanoparticles from UV-visible light spectra. Analyst 2014, 139, (19), 4855-4861.

52. White, P.; Hjortkjaer, J., Preparation and characterisation of a stable silver colloid for SER (R) $S$ spectroscopy. Journal of Raman Spectroscopy 2014, 45, (1), 32-40. 
53. Siiman, O.; Feilchenfeld, H., Internal fractal structure of aggregates of silver particles and its consequences on surface-enhanced Raman scattering intensities. The Journal of Physical Chemistry 1988, 92, (2), 453-464.

54. Cid-Andres, A. P., A review on useful concepts for stable isotope of oxygen in phosphate ( $\delta 180 p)$ extraction, purification and analysis of freshwater samples and other potential phosphate sources. Microchemical Journal 2015, 123, 105-110.

55. Devi, L. B.; Mandal, A. B., Interaction of Silver Nanoparticles with DNA Building Blocks. 2011.

56. Baalousha, M.; Motelica-Heino, M.; Le Coustumer, P., Conformation and size of humic substances: Effects of major cation concentration and type, $\mathrm{pH}$, salinity, and residence time. Colloids and surfaces A: physicochemical and engineering aspects 2006, 272, (1), 48-55.

57. Diegoli, S.; Manciulea, A. L.; Begum, S.; Jones, I. P.; Lead, J. R.; Preece, J. A., Interaction between manufactured gold nanoparticles and naturally occurring organic macromolecules. Sci Total Environ 2008, 402, (1), 51-61.

58. Chen, K. L.; Elimelech, M., Influence of humic acid on the aggregation kinetics of fullerene (C60) nanoparticles in monovalent and divalent electrolyte solutions. Journal of Colloid and Interface Science 2007, 309, (1), 126-134.

59. Wang, B.; Zhu, Q. K.; Liao, D. L.; Yu, C., Perylene probe induced gold nanoparticle aggregation. Journal of Materials Chemistry 2011, 21, (13), 4821-4826.

60. Zhang, H. Y.; Smith, J. A.; Oyanedel-Craver, V., The effect of natural water conditions on the antibacterial performance and stability of silver nanoparticles capped with different polymers. Water Research 2012, 46, (3), 691-699.

61. Hu, Z. S.; Oskam, G.; Penn, R. L.; Pesika, N.; Searson, P. C., The influence of anion on the coarsening kinetics of ZnO nanoparticles. Journal of Physical Chemistry B 2003, 107, (14), 3124-3130.

62. Wagner, S.; Gondikas, A.; Neubauer, E.; Hofmann, T.; von der Kammer, F., Spot the Difference: Engineered and Natural Nanoparticles in the Environment-Release, Behavior, and Fate. Angewandte Chemie-International Edition 2014, 53, (46), 12398-12419. 

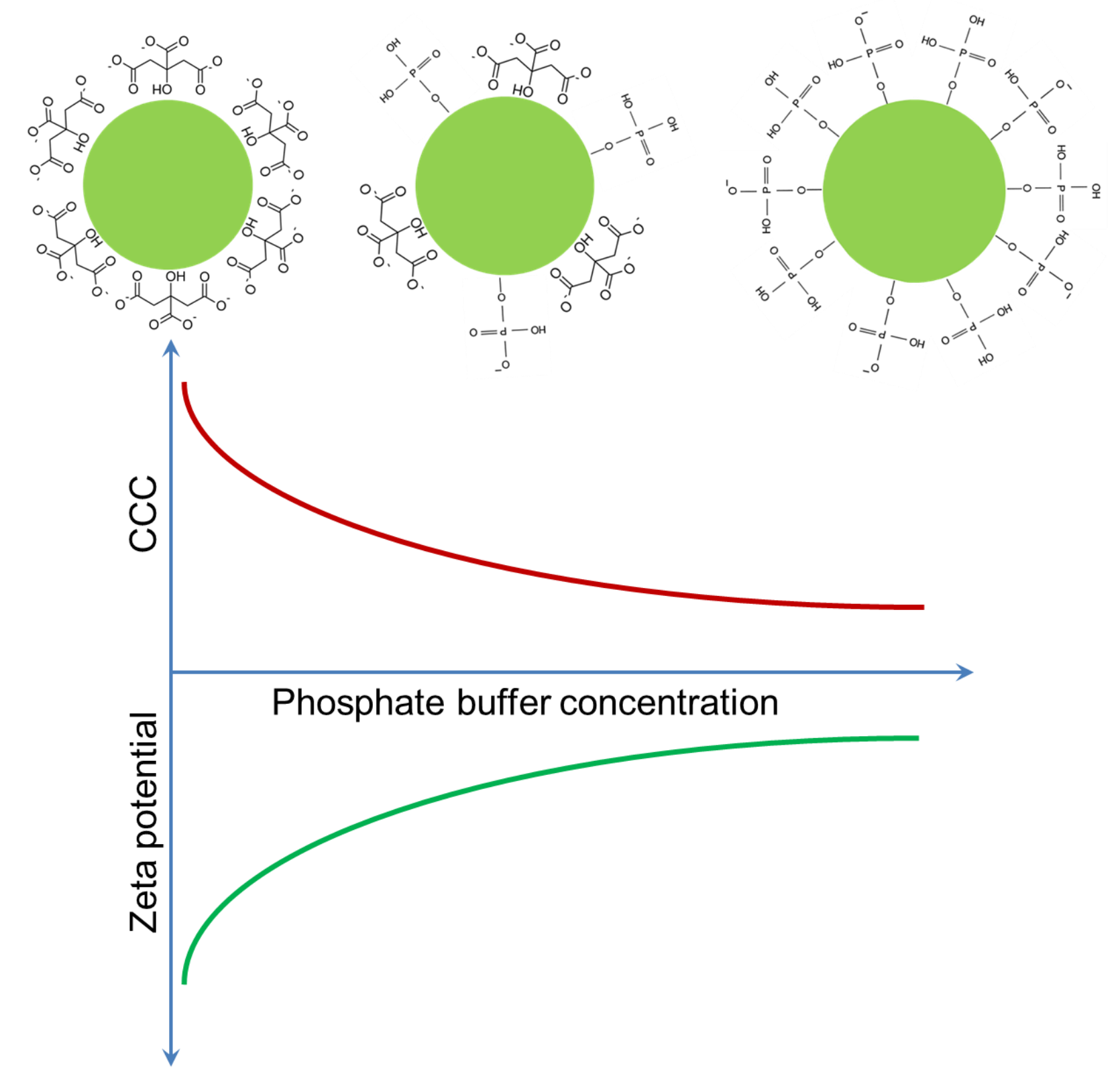

\section{Graphical Abstract}

